\title{
The archaic and puzzling record of Lake Xere Wapo, New Caledonia
}

\section{Janelle Stevenson}

Archaeology and Natural History, ANU College of Asia and the Pacific, Australian National University, Canberra

Janelle.Stevenson@anu.edu.au

\section{Richard Gillespie}

Archaeology and Natural History, ANU College of Asia and the Pacific, Australian National University, Canberra; School of Earth and Environmental Sciences, University of Wollongong, Wollongong

\section{Geoff Hope}

Archaeology and Natural History, ANU College of Asia and the Pacific, Australian National University, Canberra

\section{Geraldine Jacobsen}

Institute for Environmental Research, Australian Nuclear Science and Technology Organisation, Menai

\section{Stewart Fallon}

Research School of Earth Sciences, ANU College of Physical Sciences, Australian National University, Canberra

\section{Vladimir Levchenko}

Institute for Environmental Research, Australian Nuclear Science and Technology Organisation, Menai

\section{Introduction}

Research into the palaeoenvironmental history of New Caledonia was begun independently by Hope and Stevenson in the early 1990s. While the original work of Hope and colleagues was centred around questions of the long-term vegetation dynamics of maquis and rainforest within the ultramafic terrain of New Caledonia (Hope and Pask 1998; Read et al. 2000), Stevenson and colleagues were exploring questions of human impact and the detection of initial human 
settlement (Stevenson and Dodson 1995; Stevenson 1998; Stevenson et al. 2001; Stevenson 2004). Hope and Stevenson later came together to work on the longest record so far recovered from the tropical southwest Pacific, Lake Xere Wapo in southwest New Caledonia.

Having published the initial findings from this site (Stevenson and Hope 2005), a major problem remained, that of a robust chronology. The $12 \mathrm{~m}$ core XW-B reached radiocarbon background shortly after $300 \mathrm{~cm}$, had several significant age inversions and had what appeared to be a very shallow Holocene sequence of fewer than $20 \mathrm{~cm}$. Stevenson and Hope revisited Lake Xere Wapo in 2005, collecting new material for further dating aimed at untangling the chronology. Results from this new dating program are reported here, with a summary of previous radiocarbon determinations.

\section{Environmental setting}

New Caledonia (20-23 $\mathrm{S}$ and $164-167^{\circ} \mathrm{E}$; Figure 1) has a tropical to subtropical climate influenced by the prevailing southeast trade winds. The average annual rainfall for the region is around $3000 \mathrm{~mm} \mathrm{yr}^{-1}$, with the warmest and wettest months being from December to April and the driest from August to November. Annual rainfall is also highly variable and years of rainfall shortage are linked to the El Niño - Southern Oscillation (ENSO) phenomenon (Morliere and Rebert 1986).

The archipelago is probably best known for its rich and distinctive flora, with the high rate of endemism ( $80 \%$ of an estimated 3000 species) thought to occur as a result of its Gondwanan origins and the unusual ultramafic terrain that covers approximately one third of the main island (Morat et al. 1984). Within this terrain at the southeast end of the island is the Plaine des Lacs, an old plateau around $180-250 \mathrm{~m}$ in altitude and crossed by a series of low ridges separated by gently sloping areas with numerous lakes. Within this terrain lies Lake Xere Wapo $\left(22^{\circ} 17.5^{\prime} \mathrm{S}, 166^{\circ} 58.5^{\prime} \mathrm{E}\right)$ at an altitude of $220 \mathrm{~m}$ (Figures 1 and 2). The lake is roughly triangular in plan, is approximately $0.85 \mathrm{~km}^{2}$ in area and has a catchment consisting of the area within $-100 \mathrm{~m}$ of the lake. The lake is usually shallow, only $1-2 \mathrm{~m}$ in depth, with shelves of laterite on the northern shoreline flooded on occasion. There are no feeder streams and it is thought that the basin formed by solution, possibly influenced by some fault control, with the lake rising after heavy rain and draining underground to the Wajana River.

The gentle slopes that surround Lake Xere Wapo are an ultramafic complex of hartzbergite and serpentinite mostly covered in a ferritic soil mantle, although in places characterised by an iron pan crust known as 'sols cuirasse'. These soils are high in iron, magnesium, manganese and nickel, and plant growth is challenged by a lack of phosphorous, potassium and nitrogen. Vegetation on ultramafic substrates therefore tends to have a distinct species composition, rich in local endemics and lacking species from adjacent substrates. In many parts of the world, the ultramafic floras are species-poor (Brooks 1987), but in New Caledonia the species diversity of the ultramafic terrain is high and the vegetation ranges from stunted maquis (heath-shrubland) to structurally complex rainforest, with many of the rainforest species not confined to the ultramafic substrate.

The vegetation surrounding Lake Xere Wapo is characterised by a bushy maquis dominated by either Gymnostoma deplancheanum or Dacrydium araucarioides, with various Myrtaceae forming a denser, closed scrub down to the water's edge (examples: Austromyrtus altemifolius, Babingtonia lerattii, Melaleuca gnidioides, Syzygium ngoyensis, Tristaniopsis glauca, T. guillaimii, Uromyrtus myrtoides, U. emarginata). Two sedges (Costularia xyridioides and Schoenus brevifolius) grow in the shallow water margins. The low nutrient status for all lakes and streams within this landscape is evident from the sparseness of aquatic flora and fauna. 


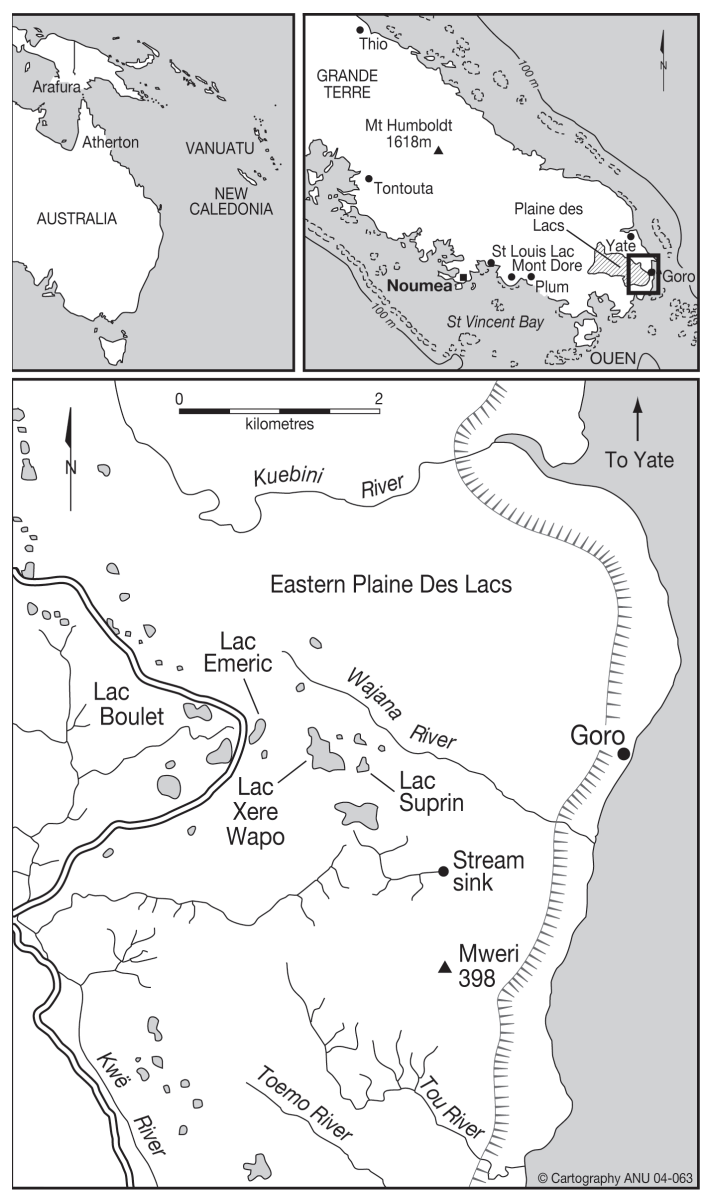

Figure 1. Location map of Lake Xere Wapo within the Plaine des Lacs region of New Caledonia

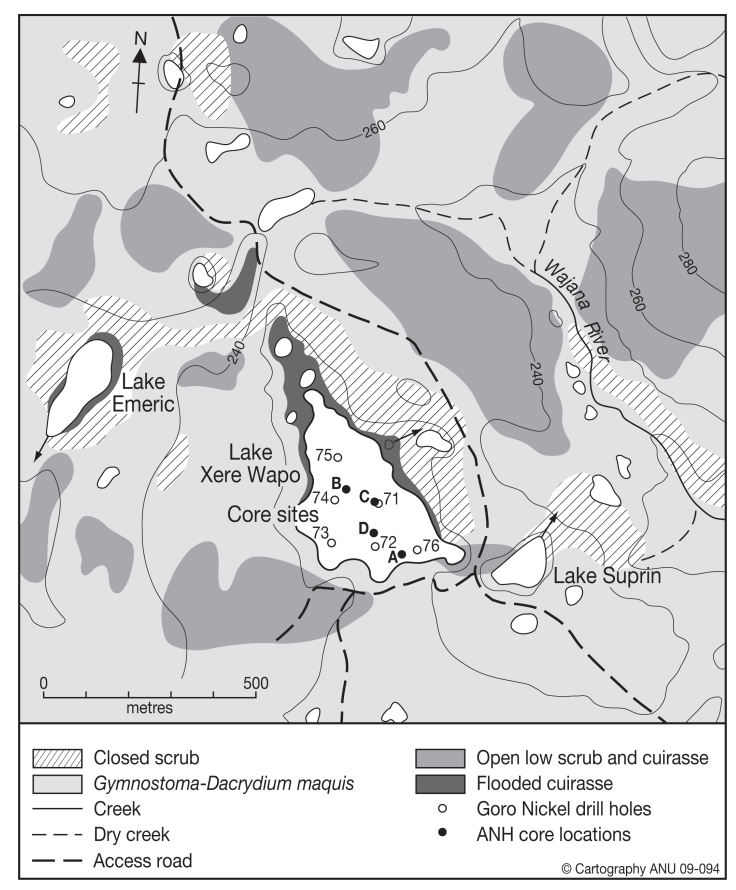

Figure 2. Site map of Lake Xere Wapo showing coring locations

Of note is that, while the diversity of the dicotyledonous flora of the Plaines des Lacs region is high, grasses are absent.

\section{Methods and materials}

\section{Lake sediment coring}

Sediment core locations for Lake Xere Wapo are shown in Figure 2. A $50 \mathrm{~cm}$ core, XW-A, was taken in June 1992, about $25 \mathrm{~m}$ from the southern edge of the lake, and a $1280 \mathrm{~cm}$ core, XW-B, was taken in December 1994 from the centre of the lake in a water depth of $-60 \mathrm{~cm}$. In both cases, sediment was collected with a D-section corer, except for the interval $1000 \mathrm{~cm}$ to $1280 \mathrm{~cm}$ in XW-B, where a Livingston piston corer was used. Core XW-B was chosen for the pollen and charcoal analyses, published in Stevenson and Hope (2005), given the greater depth of sediment recovered. Some difficulty was encountered in collecting material from the upper $3 \mathrm{~m}$, however, as several quite fluid horizons were encountered.

At location XW-C in 2005, a $60 \mathrm{~cm}$ mud-water interface core was collected and extruded in the field into $0.5 \mathrm{~cm}$ slices. Lake sediments were also sampled from 30-230 $\mathrm{cm}$ at this location with a D-Section corer as the upper sediments were too loose for collection with a Livingstone corer. An attempt was made to collect sediments from 200 $\mathrm{cm}$ onwards (giving a $30 \mathrm{~cm}$ overlap with the D-Section cores) with a Livingston corer. However, two major woody layers at $290 \mathrm{~cm}$ and $340 \mathrm{~cm}$ prevented further collection using either coring system. Operations were therefore moved to site XW-D (see Figure 2), 
where sediments from $150-850 \mathrm{~cm}$ were recovered using a combination of D-Section and Livingstone corers.

In 2001, the company Vale Inco Nouvelle Calédonie drilled Lake Xere Wapo as part of a mining survey for the Goro Nickel plant (Figure 2). This drilling survey reinforced how difficult the sediments are to collect, as all five drill locations had extremely poor recovery down to 7-9 m. Below this, however, the drillers were able to recover more compact lake muds to a maximum depth of $25 \mathrm{~m}$. Drill hole 01RG-76 from the Goro Nickel drilling program had the best and deepest recovery, at $25.2 \mathrm{~m}$, with this and the other cores held in cool storage at the Grand Lac mining camp. Because an aim of the 2005 field season was to extend the record of XW-B, 01RG-76 was sampled at $10 \mathrm{~cm}$ intervals from $6.3 \mathrm{~m}$ to $20.35 \mathrm{~m}$.

At the time of the 2005 field season, the layout of the mining survey was not known. That information became available at a later date, revealing that core location XW-C is in close proximity to drill hole 01RG-71, with the drilling notes revealing that three attempts were made to collect material from the site and only on the third attempt was there reasonable recovery.

\section{Radiocarbon dating}

So far, 31 samples from five Xere Wapo cores have been analysed by four radiocarbon laboratories, one using radiometric techniques (ANU) and three using AMS (OZ, SANU and Wk codes), along with a variety of physical and chemical pre-treatments. Radiocarbon and stable-isotope measurements were made using standard procedures at the respective laboratories (e.g. Fink et al. 2004; Hogg et al. 2006)

For the bulk sediment sample from $115-123 \mathrm{~cm}$ in core XW-A, the $<500 \mu \mathrm{m}$ fraction was solvent extracted, then given standard hot acid-base-acid (ABA) chemistry. Samples from core XW-B comprised three wood and three 250-600 $\mu \mathrm{m}$ bulk sediment fractions, all treated with hot $\mathrm{HCl}$ only. For later sediment samples from core XW-B, the 10-250 $\mu \mathrm{m}$ pollen size fractions were treated with cold $\mathrm{HCl}$, cold $\mathrm{HF}$, warm $\mathrm{KOH}$ and cold $\mathrm{HCl}$. Similar pre-treatment was applied to samples from XW-C and XW-D, but on the 10-125 $\mu \mathrm{m}$ fraction.

Four paired sediment and wood samples from cores XW-C and 01RG-76 were processed in 2009. Sediment samples were treated with cold $\mathrm{NaOCl}, \mathrm{HCl}$, warm $\mathrm{NaOH}$ and $\mathrm{HCl}(\mathrm{OxABA})$, then sieved to produce a pollen-rich size fraction of 38-50 $\mu \mathrm{m}$; the dominant pollen type was Dacrydium, which varied from $30 \%$ to $70 \%$ of the total fraction. Wood samples were treated with two cycles of cold $\mathrm{NaOCl}$, hot $\mathrm{HCl}$, hot $\mathrm{pH} 3$ $\mathrm{NaClO}_{2}$, hot $\mathrm{NaOH}, \mathrm{HCl}(\mathrm{OxAOxBA})$. Because these waterlogged wood samples were cut into matchstick-size slices with a scalpel, complete decontamination may not have been achieved; reference standard New Zealand kauri wood samples, ground to $<1 \mathrm{~mm}$ and treated with two cycles of cold $\mathrm{NaOCl}$, hot $\mathrm{pH} 3 \mathrm{NaClO}_{2}$ and $\mathrm{HCl}$ (OxAOxA), produced clean white cellulose which yielded consistent results (OZL-485 and 486). The hypochlorite and chlorite oxidation (bleaching) steps are based on chemistry discussed in Gillespie et al. (2008).

\section{Results}

\section{Stratigraphy}

The Goro Nickel drilling program provides an overview of the depth of organic sediment within the lake (Figure 3). That drilling program and the hand coring carried out by Stevenson and Hope reveal that the surface sediments of Lake Xere Wapo are firm and the lake bed appears to have no discernable topography. Underlying this, however, are many fluid horizons, possibly resulting from voids within and around tree debris (Figure 4). Wood fragments have been 

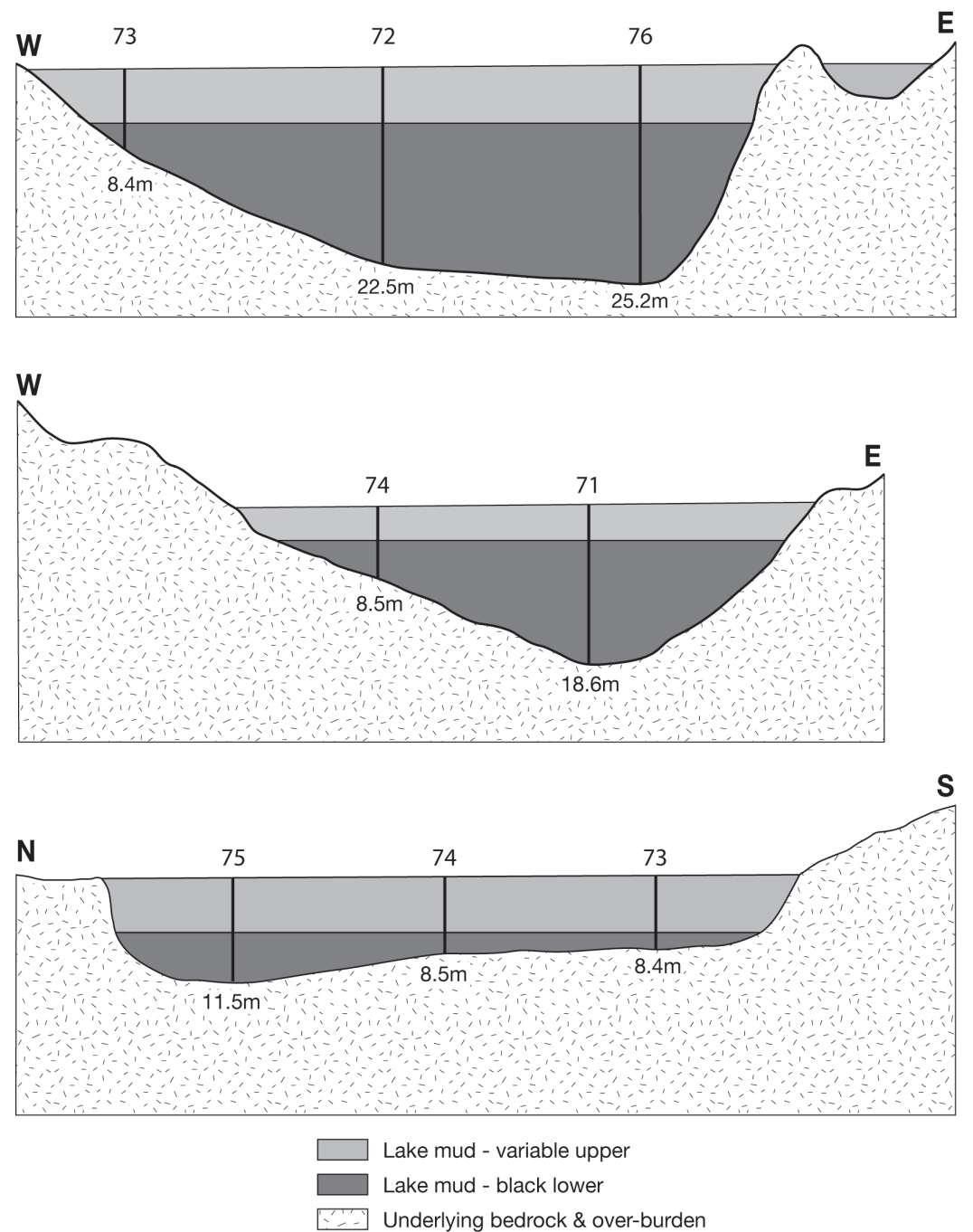

Figure 3. Goro Nickel survey sections

noted at various depths in the Lake Xere Wapo sediments. Wood from a similar context in Lake Suprin (see Figure 1), but with better preservation, has been identified as the freshwater mangrove conifer Retrophyllum minor (Hope and Pask 1998). The wood from Lake Xere Wapo is from several taxa, including $R$. minor, and is indicative of considerable fluctuations in water level.

Sediment descriptions of XW-A to XW-D as well as 01RG-76 are set out in Table 1 and a stratigraphic diagram illustrating the major changes in sediment type is shown in Figure 5. Across the cores there are several correlating units. Prominent among these are the black organic mud layers at $150-175 \mathrm{~cm}$ in XW-B, 101-172 cm in XW-C, $150-160 \mathrm{~cm}$ in XW-D, $35-100 \mathrm{~cm}$ in XW-A and from $60-70 \mathrm{~cm}$ in $01 \mathrm{RG}-76$. In all cases this unit is underlain by dark yellowish brown clay (10YR 4/3-4/6) and, depending on location within the lake, this unit can be extremely fluid. In the original cores collected by Hope, this layer was described (without a Munsell chart description) as an orange clay. The next stratigraphic unit common to all the cores is another dark yellowish brown clay unit, which like the unit above, is also very fluid. However, the major sedimentary unit common to all of the deeper cores is the black organic mud that commences at $300 \mathrm{~cm}$ in XW-B, $356 \mathrm{~cm}$ in XW-D, and $275 \mathrm{~cm}$ in $01 \mathrm{RG}-76$. From $660-2030 \mathrm{~cm}$ in the $01 \mathrm{RG}-76$ core, the sediment is predominantly this very dark grey mud, with punctuations of lighter coloured sediment from $1530-1580 \mathrm{~cm}$ (dark grey), 1660-1720 cm (dark olive brown), and 1945-2030 (dark grey brown-dark olive brown). These black/grey muds and clays comprise the bulk of the sediment in the lake and 
Table 1. Sediment core descriptions (see Figure 2 for locations) (Table 1 continues on page 389)

\begin{tabular}{|c|c|}
\hline Depth (cm) & XW-A \\
\hline $0-15$ & Sloppy-brown organic mud with wood fragments \\
\hline $15-35$ & Orange-brown mud \\
\hline $35-100$ & Black organic mud \\
\hline $100-138$ & Orange-brown mud \\
\hline $138-290$ & Brown organic mud with thin white clay band at $160 \mathrm{~cm}$ \\
\hline $290-302$ & Brown-orange mud \\
\hline $302-455$ & Brown-organic mud with wood at $310-330,430-440$ \\
\hline \multirow[t]{2}{*}{$455->500$} & Grey silty clay and coarser mineral particles \\
\hline & XW-B \\
\hline $0-25$ & Yellow-brown organic clay \\
\hline $25-40$ & Dark-brown clayey organic mud - fine yellow band $32 \mathrm{~cm}$ \\
\hline $40-45$ & Brown organic clay \\
\hline $45-125$ & Black organic mud - fine yellow clay band at $90 \mathrm{~cm}$, wood from $90-125 \mathrm{~cm}$ \\
\hline $125-140$ & Brown organic mud \\
\hline $140-150$ & Wood - in matrix of black mud \\
\hline $150-165$ & Black organic mud \\
\hline $162-175$ & Wood - in matrix of black mud \\
\hline $175-180$ & Orange clay \\
\hline $180-200$ & Brown organic mud \\
\hline $200-240$ & Dark-brown organic mud, wood and roots at 222 and 238 \\
\hline $240-265$ & Light-brown/orange clay with wood fragments \\
\hline $265-300$ & Dark-brown organic mud - lighter colour + wood 275-280 \\
\hline $300-610$ & $\begin{array}{l}\text { Black org. mud - coarse, grading into fine from 460-480 (grey clay 410-415; wood @ 470-480, } \\
600 \text { ) }\end{array}$ \\
\hline $610-650$ & Grey mud \\
\hline $650-1100$ & Black organic mud \\
\hline $0-14$ & Dark yellowish-brown mud \\
\hline Depth $(\mathrm{cm})$ & $\mathrm{XW}-\mathrm{C}$ \\
\hline $14-18$ & Transition to very dark-brown mud \\
\hline $18-26$ & Very dark-brown mud \\
\hline $26-28$ & Transition to very dark grey-brown mud \\
\hline $28-30$ & Very dark grey-brown mud \\
\hline $30-50$ & Very dark-brown organic mud - wood $31-36 \mathrm{~cm}$, rootlets at $42 \mathrm{~cm}$, wood $50-53 \mathrm{~cm}$ \\
\hline $50-53$ & Dark yellowish-brown clay - loose and watery with lots of wood \\
\hline $53-60$ & Very dark-brown mud - voids filled with dark yellowish-brown mud \\
\hline $60-101$ & Dark yellowish-brown mud with rootlets \\
\hline $101-172$ & Black organic mud - lots of wood and other organic debris - yellow bands at 149 and 156 \\
\hline $172-185$ & Wood in a matrix of dark yellowish-brown clay - very fluid \\
\hline $185-187$ & Dark yellowish-brown clay - no wood \\
\hline \multirow[t]{2}{*}{$187-230$} & Grades into very dark grey-brown organic clay - wood at 190, 193-196, 199-205, 214-223 \\
\hline & XW-D \\
\hline $150-159$ & Black organic mud \\
\hline $159-173$ & Dark yellowish-brown clay - gravels at 163-167 \\
\hline $173-280$ & Dark-brown organic clay - very fluid \\
\hline $280-335$ & Dark yellowish-brown clay \\
\hline $335-356$ & Dark greyish-brown mud \\
\hline
\end{tabular}




\begin{tabular}{|l|l|}
\hline $356-850$ & Black organic mud - wood at 358-362 and 635-650 \\
\hline $0-58$ & 01RG-76 \\
\hline $58-63$ & Dark yellowish-brown clay \\
\hline $63-265$ & Black organic mud \\
\hline $265-275$ & Very dark-brown mud - wood and roots at 180-185 \\
\hline $275-670$ & Dark yellowish-brown mud - wood throughout - very fluid \\
\hline $670-1660$ & Black - wood throughout from 295 \\
\hline $1660-1720$ & $\begin{array}{l}\text { V. dark grey mud - fine roots and wood throughout - olive-brown mud with roots and small } \\
\text { wood fragments from 710-740 }\end{array}$ \\
\hline $1720-1835$ & Dark olive-brown slightly organic clay \\
\hline $1835-1950$ & Changes gradually to very dark grey clay - wood and roots from 1825-1835 - less consolidated \\
\hline $1950-1990$ & Black organic mud - unconsolidated at time of collection \\
\hline $1990-2035$ & Very dark grey-brown - wood from 1980-1990 \\
\hline
\end{tabular}

Note: 01RG-76 description from Goro Nickel core logs. Colours descriptions are based on the Munsell colour chart.

are seen in the other Goro Nickel drill holes (Figure 3). Many of the cores have extremely poor recovery for the upper $2-4 \mathrm{~m}$ due to the highly fluid nature of the sediments, resulting in the uppermost black unit missing from many of these locations.

Wood layers are noted throughout the cores, but the greatest concentration is in cores closer to the current shoreline. XW-D contains the least woody debris, suggesting that this may be the location where greater water depth has been most consistent over time.

\section{Chronology}

All ${ }^{14} \mathrm{C}$ determinations for Lake Xere Wapo are listed in Table 2, and are shown against depth in the schematic core stratigraphy for XW-A to D and 01RG-76 (Figure 5).

Results for cores XW-A and XW-B were discussed by Stevenson and Hope (2005). The sample from $96-107 \mathrm{~cm}$, originally reported as a bulk sediment sample, was in fact the $>600 \mu \mathrm{m}$

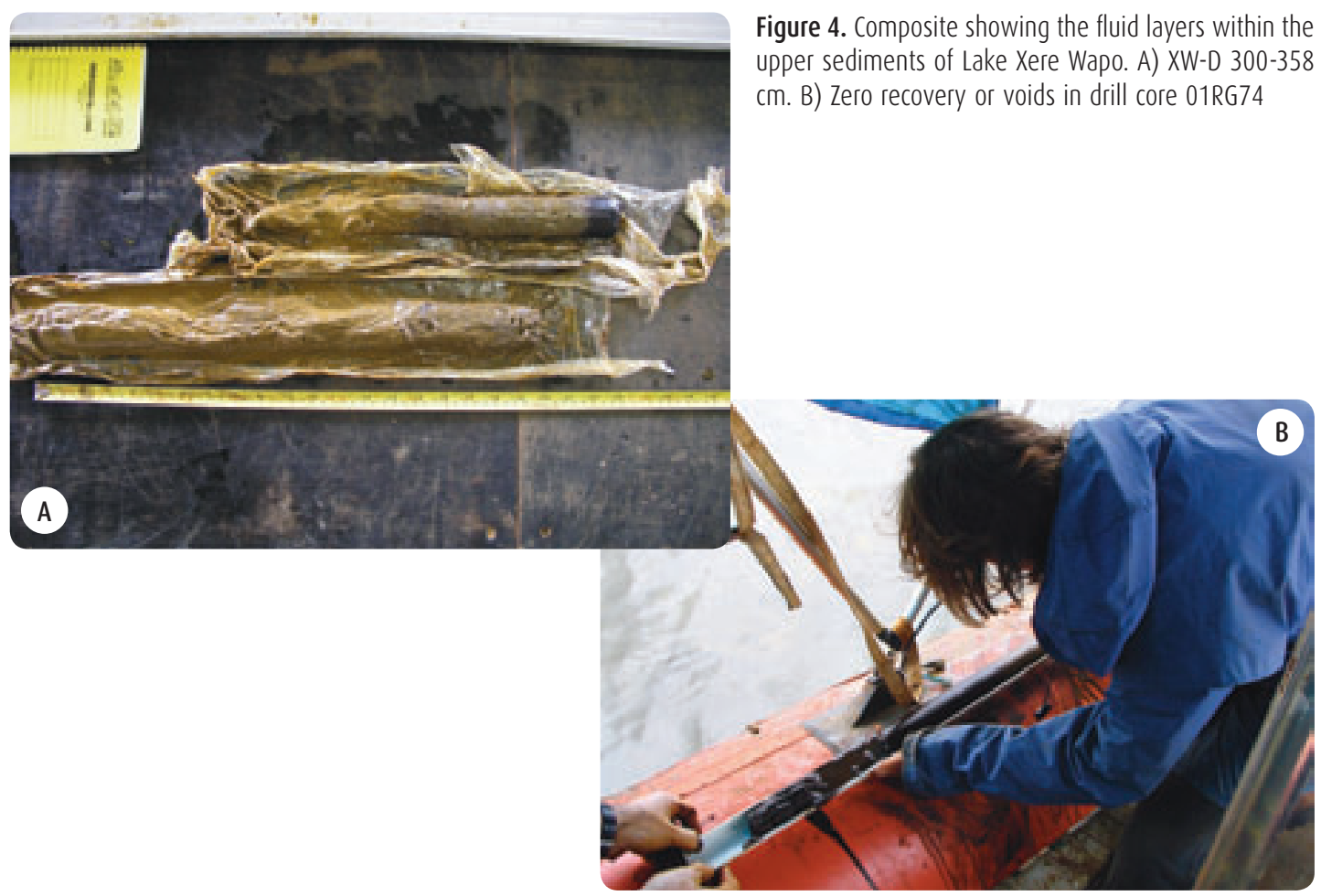




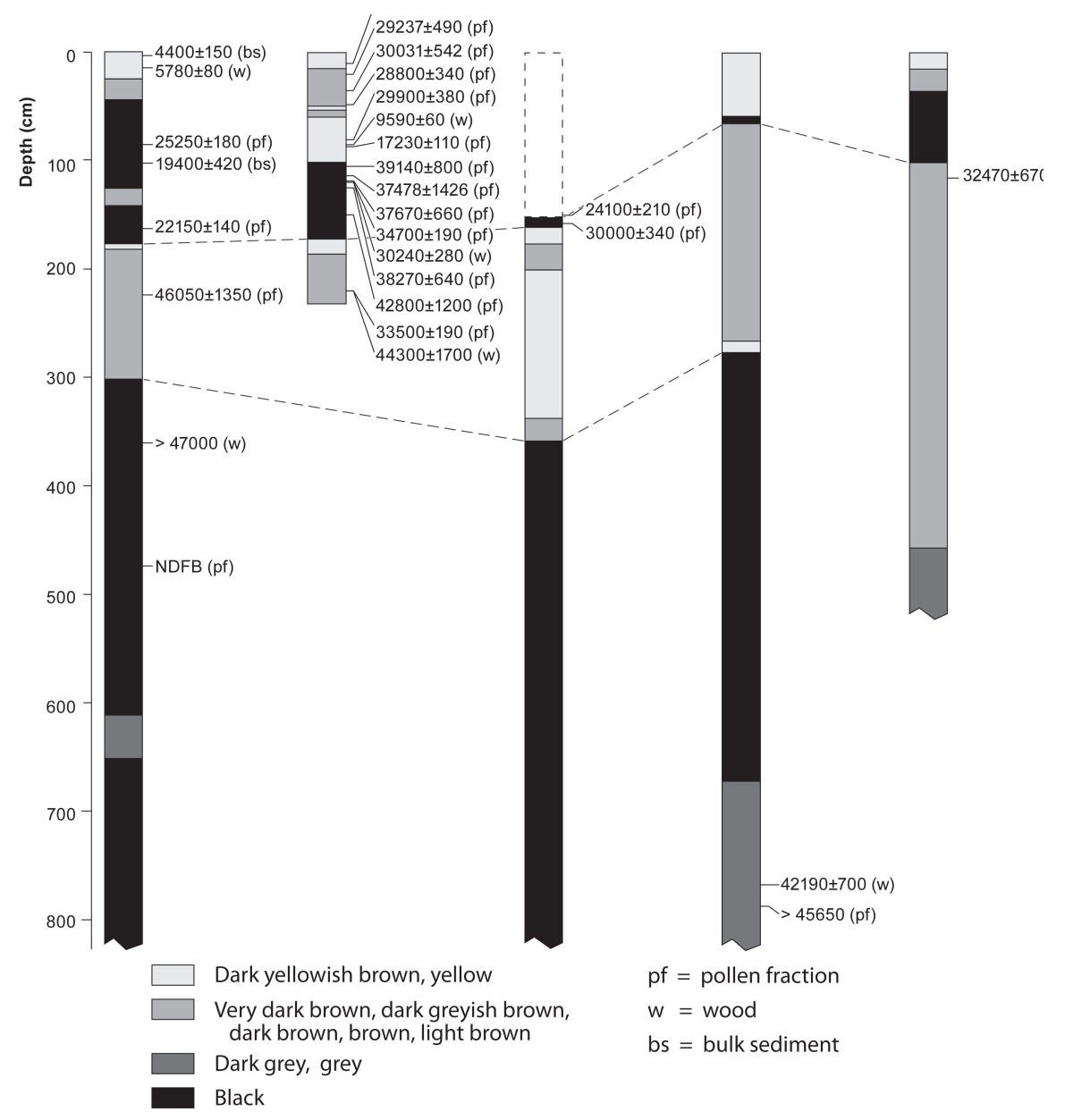

Figure 5. Schematic of core stratigraphy for XW-A to XW-D and 01RG-76, with age determinations

fraction, composed largely of small twigs; it is therefore now viewed as a wood sample. Extreme age inversions were also noted at $250-270 \mathrm{~cm}$ and $290-300 \mathrm{~cm}$, and laboratory records indicate these two samples were unusually small for a conventional radiocarbon date; they were dropped from any discussion concerning the chronology. Further results from pollen-size fractions produced another age inversion, with background reached at $360 \mathrm{~cm}$ in the core XW-B.

Because the fluid yellow-brown layers have always been considered to stem from disturbance within the catchment, the focus for fresh material collected in 2005 was on the black, highly organic layers, as they were likely to be indicative of greater stability. Four samples were dated from field-extruded $5 \mathrm{~mm}$ slices of the XW-C mud-water interface section in an attempt to construct a better Holocene chronology. The sample from $10 \mathrm{~cm}$ returned an age of $8792 \pm$ 53 (Wk-18065), but four samples covering $20 \mathrm{~cm}$ to $81 \mathrm{~cm}$ depth are surprisingly old and statistically indistinguishable at $1 \sigma$, with an error-weighted mean age of 29,540 $\pm 220 \mathrm{BP}$. Four pollen size fractions from the black organic mud layer spanning $101 \mathrm{~cm}$ to $126 \mathrm{~cm}$ in XW-C are also statistically indistinguishable at $1 \sigma$, with an error-weighted mean age of $37,450 \pm 380 \mathrm{BP}$, and the sample from $150-151 \mathrm{~cm}$ at the base of this black organic mud unit in XW-C returned an age of 42,800 \pm 1200 (OZJ-298). Two samples from the bottom $9 \mathrm{~cm}$ of the corresponding unit in core XW-D returned ages in stratigraphic order at 24,100 \pm 210 (OZJ-293) and 30,000 $\pm 340(\mathrm{OZJ}-294)$.

The latest round of dating on the Lake Xere Wapo sediments, using paired wood cellulose and pollen-rich preparations, adds further disarray to an already confusing set of radiocarbon ages. For the three sample pairs from core XW-C, each pair has significantly different ages and both the $85-87 \mathrm{~cm}$ and $119-121 \mathrm{~cm}$ pairs are out of sequence with the two pooled 
means noted above. The much deeper pair from drill core 01RG-76 also returned significantly different ages, with the wood cellulose at 42,190 $\pm 700 \mathrm{BP}(\mathrm{OZL}-484)$ and the pollen-rich fraction (SANU-8320) not distinguishable from background.

The graph in Figure 6 plots ${ }^{14} \mathrm{C}$ age against $\delta^{13} \mathrm{C}$, showing the expected difference between wood cellulose at $\delta^{13} \mathrm{C}=-20$ to $-22 \%$ and the pollen-rich organics, most of which have $\delta^{13} \mathrm{C}$ $=-27$ to $-30 \%$. The four samples at $\delta^{13} \mathrm{C}=-23$ to $-25 \%$ appear anomalous, less negative than other pollen-rich samples, but the oldest three of these were given hypochlorite oxidation plus ABA chemistry, which is expected to significantly reduce humic acids and other lignin-derived organics, thus moving $\delta^{13} \mathrm{C}$ of residual non-pollen plant debris towards the cellulose values.

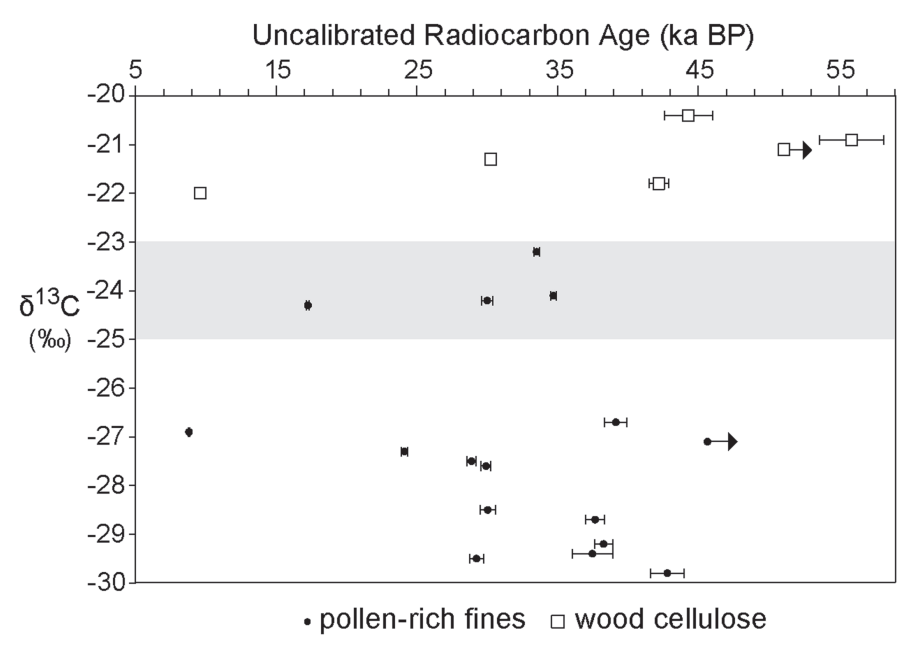

Figure 6. Radiocarbon age against $\delta^{13} \mathrm{C}(\% 0)$

\section{Discussion}

The most consistent unit dated between cores is the yellow-brown lake surface sediment that has a varying depth of $15-58 \mathrm{~cm}$ across the basin. In XW-B, this unit is $25 \mathrm{~cm}$ thick and returned two mid-Holocene dates. In XW-C, this surface layer is $14 \mathrm{~cm}$ thick and a sample from $10 \mathrm{~cm}$ returned an early Holocene age. These Holocene dates suggest that this most recent sedimentary unit may have started accumulating around 10,000-12,000 $\mathrm{BP}$, and be indicative of (1) how slowly these sediments accumulate, and (2) the potential age of all underlying sediments. The next most consistent unit within the lake sediment is the upper black organic mud unit in cores XW-B, XW-C and XW-D. However, samples dated from the base of this unit in the three different cores $(163 \mathrm{~cm}, 150 \mathrm{~cm}, 158 \mathrm{~cm})$ returned ages of 22,150 BP, 42,800 BP and 29,910 BP respectively, suggesting no horizontal correlation in age. Another curiosity in the dating of Xere Wapo is that by $20 \mathrm{~cm}$, the XW-C ages have already reached 29,540 BP, although there is no discernable stratigraphic hiatus in the sediments to explain this sudden shift in age.

The paired dating of wood and pollen-rich samples from these layers was carried out to resolve this issue. Vandergoes and Prior (2003) and a follow up study Newnham et al. (2007) highlighted the difficulties of dating the organic fraction in old sediments from several lakes and swamps in a high rainfall area of southern New Zealand. They concluded that it was the accompanying fine organic fraction in some pollen concentrates that caused young carbon contamination, or in some cases, the incomplete removal of humic acids that may have entered the older sediments through root penetration. The paired dating exercise in this study produced mixed results, with three out of the four pollen-rich dates being older than 
Table 2. Carbon isotope analyses. Radiocarbon determinations by Australian National University (ANU radiometric, SANU accelerator), University of Waikato (Wk accelerator (in collaboration with UC Irvine)), Australian Nuclear Science and Technology Organisation (OZ accelerator). Pre-treatment chemistry: $A=$ acid only; $A B A=$ acid, base, acid; 0xABA = hypochlorite, acid, base, acid; 0xA0xBA = hypochlorite, acid, chlorite, base, acid; 0xA0xA = hypochlorite, acid, chlorite, acid; all with distilled water washes between reagents. Reference standards are ancient NZ kauri wood samples courtesy of Alan Hogg, Waikato. NDFB = not different from background

\begin{tabular}{|c|c|c|c|c|c|c|}
\hline Core & Depth $(\mathrm{cm})$ & Fraction dated & Chemistry & $\delta^{13} \mathrm{C}(\%)$ & ${ }^{14} \mathrm{C}$ Age (yr BP) & Lab number \\
\hline XW-A & $115-123$ & bulk sediment $<500 \mu \mathrm{m}$ & solvent, $\mathrm{ABA}$ & -24.0 (est.) & $32,470 \pm 670$ & ANU-8420 \\
\hline \multirow[t]{10}{*}{ XW-B } & $3-4$ & bulk sediment $250-600 \mu \mathrm{m}$ & A & -24.0 (est.) & $4400 \pm 150$ & ANU-9797 \\
\hline & $10-20$ & whole wood & A & -24.0 (est.) & $5780 \pm 80$ & ANU-9793 \\
\hline & $83-85$ & pollen-rich $10-250 \mu \mathrm{m}$ & ABA & N/A & $22,150 \pm 140$ & OZF-756 \\
\hline & $96-107$ & whole wood $>600 \mu \mathrm{m}$ & A & -24.0 (est.) & $19,400 \pm 420$ & ANU-9794 \\
\hline & $163-164$ & pollen-rich $10-250 \mu \mathrm{m}$ & $\mathrm{ABA}$ & N/A & $25,250 \pm 180$ & OZF-755 \\
\hline & $223-225$ & pollen-rich $10-250 \mu \mathrm{m}$ & ABA & N/A & $46,050 \pm 1350$ & OZF-757 \\
\hline & $250-270$ & bulk sediment $250-600 \mu \mathrm{m}$ & A & -24.0 (est.) & $8500 \pm 420$ & ANU-9795 \\
\hline & $290-300$ & bulk sediment $250-600 \mu \mathrm{m}$ & A & -24.0 (est.) & $14,660 \pm 660$ & ANU-9796 \\
\hline & 360 & whole wood & $\mathrm{ABA}$ & N/A & $>47,000$ & OZE-449 \\
\hline & 475 & pollen-rich $10-250 \mu \mathrm{m}$ & $\mathrm{ABA}$ & N/A & NDFB & OZE-448 \\
\hline \multirow[t]{16}{*}{ XW-C } & $10-10.5$ & pollen-rich $10-125 \mu \mathrm{m}$ & $\mathrm{ABA}$ & -26.9 & $8792 \pm 53$ & Wk-18065 \\
\hline & $20-20.5$ & pollen-rich $10-125 \mu \mathrm{m}$ & $\mathrm{ABA}$ & -29.5 & $29,237 \pm 490$ & Wk-18066 \\
\hline & $35-35.5$ & pollen-rich $10-125 \mu \mathrm{m}$ & $\mathrm{ABA}$ & -28.5 & $30,031 \pm 542$ & Wk-18067 \\
\hline & $48-49$ & pollen-rich $10-125 \mu \mathrm{m}$ & $\mathrm{ABA}$ & -27.5 & $28,880 \pm 340$ & OZJ-295 \\
\hline & $80-81$ & pollen-rich $10-125 \mu \mathrm{m}$ & $\mathrm{ABA}$ & -24.2 & $29,990 \pm 380$ & OZJ-296 \\
\hline & $85-86$ & wood cellulose & OxAOxBA & -22.0 & $9590 \pm 60$ & OZL-481 \\
\hline & $86-87$ & pollen-rich $38-50 \mu \mathrm{m}$ & OxABA & -24.3 & $17,250 \pm 110$ & SANU-8316 \\
\hline & $105-106$ & pollen-rich $10-125 \mu \mathrm{m}$ & $\mathrm{ABA}$ & -26.7 & $39,140 \pm 800$ & OZJ-297 \\
\hline & $110-111$ & pollen-rich $10-125 \mu \mathrm{m}$ & $\mathrm{ABA}$ & -29.4 & $37,478 \pm 1426$ & Wk-17760 \\
\hline & $115-116$ & pollen-rich $10-125 \mu \mathrm{m}$ & $\mathrm{ABA}$ & -28.7 & $37,670 \pm 660$ & OZJ-291 \\
\hline & $119-120$ & pollen-rich $38-50 \mu \mathrm{m}$ & OxABA & -24.1 & $34,700 \pm 190$ & SANU-8317 \\
\hline & $120-121$ & wood cellulose & OxAOxBA & -21.3 & $30,240 \pm 280$ & OZL-482 \\
\hline & $125-126$ & pollen-rich $10-125 \mu \mathrm{m}$ & $\mathrm{ABA}$ & -29.2 & $38,270 \pm 640$ & OZJ-292 \\
\hline & $150-151$ & pollen-rich $10-125 \mu \mathrm{m}$ & ABA & -29.8 & $42,800 \pm 1200$ & OZJ-298 \\
\hline & $219-220$ & pollen-rich $38-50 \mu \mathrm{m}$ & OxABA & -23.2 & $33,500 \pm 190$ & SANU-8318 \\
\hline & $220-221$ & wood cellulose & OxAOxBA & -20.4 & $44,300 \pm 1700$ & OZL-483 \\
\hline \multirow[t]{2}{*}{ XW-D } & $150-151$ & pollen-rich $10-125 \mu \mathrm{m}$ & $\mathrm{ABA}$ & -27.3 & $24,100 \pm 210$ & OZJ-293 \\
\hline & $158-159$ & pollen-rich $10-125 \mu \mathrm{m}$ & ABA & -27.6 & $29,910 \pm 340$ & OZJ-294 \\
\hline \multirow[t]{2}{*}{ 01RG-76 } & 770 & wood cellulose & OxAOxBA & -21.8 & $42,190 \pm 700$ & OZL-484 \\
\hline & 790 & pollen-rich $38-50 \mu \mathrm{m}$ & OxABA & -27.1 & NDFB & SANU-8320 \\
\hline \multirow[t]{4}{*}{ Ref. std. } & NZK-1 & wood cellulose & OxAOxA & -21.1 & $>51,100$ & OZL-485(1) \\
\hline & & wood cellulose & OxAOxA & -20.9 & $55,900 \pm 2300$ & OZL-485(2) \\
\hline & NZK-2 & wood cellulose & OxAOxA & -22.3 & NDFB & OZL-486(1) \\
\hline & & wood cellulose & OxAOxA & -22.2 & NDFB & OZL-486(2) \\
\hline
\end{tabular}

wood cellulose dates and several more age inversions, suggesting that contamination by young carbon through the fine organic fraction is not the main factor operating here.

The sediment fractions in this latest trial were treated with hypochlorite oxidation in an attempt to destroy organic contamination not removed by standard ABA chemistry (e.g. Gillespie 1990), and then concentrated to a size fraction of 38-50 $\mu \mathrm{m}$. The paired wood samples were converted to cellulose by a combination of alkaline hypochlorite and acidic chlorite oxidations, which produced ages consistently younger than the existing dataset. The stable isotope results presented in Table 2 are another way of looking this data. One interpretation is that they verify that the latest dating exercise has removed organic contamination (most likely humic acids and other lignin degradation products) not removed by previous methods and by doing this, has increased the cellulose content derived from non-pollen plant debris. However, the results might also indicate a significant amount of non-pollen fine plant debris in the samples. The 
source of this may be coarse non-pollen plant debris sinking through the quite fluid muds, contributing ages that are apparently too young. However, without doing more detailed work, we can't draw any firm conclusions on the reliability of the various dated fractions.

Stevenson and Hope (2005) suggested that the upper $250 \mathrm{~cm}$ of Lake Xere Wapo were most likely disturbed, possibly by in-washing of catchment sediment and erosion of shallow sediments, combined with phases of aquatic woodland interrupting deposition over the past 20,000 years. It is worth noting that a number of neighbouring lakes, such as Lake Suprin and Lake Emeric, have similar sedimentation histories for the uppermost sediments, with units of dark-yellow to reddish-brown sediments alternating with darker organic units (Hope and Pask 1998). Dating of these sediments also produced age inversions and finite dates in sediments assumed to date from beyond the radiocarbon age limit.

Given the similarity in some aspects of their pollen records, Stevenson and Hope (2005) compared the Lake Xere Wapo record with that from Lynch's Crater in northern Queensland (Kershaw 1986). Radiocarbon dating of the organic-rich Lynch's Crater sediments also produced a number of age inversions, although none as severe as those encountered in the Lake Xere Wapo dating exercises, and simple ABA pre-treatment yielded more consistent results than ABOX-SC treated samples (Acid-Base-Oxidation-Step Combustion) (Turney et al. 2001a, b). The decline of Araucaria within the past $50 \mathrm{ka}$ and increase in fire in the Australian record has been attributed variously to human impact and climate change, and remains largely unresolved. New Caledonia was not inhabited by people until c. 3000 years ago and so does not have the complicating factor of human agency, hence the importance of the record. However, a robust chronology remains elusive.

The dating of sediment cores collected by the ANU team and Goro Nickel drilling program has found that the underlying sedimentation history of the lake is more complex than first imagined, and the discussion here suggests that sediment disturbance may well be a significant factor. Fluctuations in water level and changes in sedimentary type over the past 50,000 years or more have at various times led to forest growth on the lake-bed surface. Sediments recovered in core XW-D suggest that this may be a location that had less forest incursion than other coring sites. It is this core that will now receive most attention with regard to pollen analysis and further dating. Due to the lack of free quartz in this environment, we have not been able to pursue alternative dating techniques such as optically stimulated luminescence. One avenue that may be explored is the detection of peaks in volcanic glass shards. Several peaks in volcanic glass were detected in Marine Isotope Stages 2, 3 and 4 sediments in deep-sea core Fr7/01:GC4 from the New Caledonia Basin off southern New Caledonia (Gretton 2002). If similar peaks occur in the Lake Xere Wapo sediments, then it may be possible to link and correlate the sediments with the marine stages.

\section{Conclusion}

Although some of the problems encountered in dating the Lake Xere Wapo sediments may stem from the variety of sample type and pre-treatment protocols used, later dating exercises have attempted to keep the material dated and chemistry performed more consistent. However, given the frequency of age inversions in the record - at least one in each set of radiocarbon results obtained - it is unlikely that sample contamination can explain the disparate agedepth relationships at the five core locations. Disturbance of the sediments must therefore be considered. The most recent dating programs have not resolved the problems originally reported; indeed, they add new levels of complexity and confusion to interpretations of the tempo and mode of lake-sediment formation in the Plaines des Lacs, New Caledonia. 


\section{Acknowledgements}

We thank the late John Head for ANU results, the Australian Institute for Nuclear Science and Engineering for grants AINGRA01/074 (Hope), AINGRA05/157 (Stevenson), AINGRA 090/035 (Gillespie), and the Centre for Archaeological Research, ANU (Stevenson). Thanks also to Christian Tessarolo and Stephane McCoy of Goro Nickel for providing Stevenson and Hope with all their field needs during 2005, including field assistants Tom, Gab, Max, Maggie and Rachel Lestideau.

\section{References}

Brooks, R.R. 1987. New Caledonia. In R.R. Brooks (ed.) Serpentine and its vegetation: a multidisciplinary approach. pp330-353. London.

Fink, D., M. Hotchkis, Q. Hua, G. Jacobsen, A.M. Smith, U. Zoppi, D. Child, C. Mifsud, H. van der Gaast, A. Williams and M. Williams 2004. The ANTARES AMS facility at ANSTO. Nuclear Instruments and Methods B 223-224:109-115.

Gillespie, R. 1990. On the use of oxidation for AMS sample pretreatment: Nuclear Instruments \& Methods B52:345-347.

Gillespie, R., L.K. Fifield, V. Levchenko and R. Wells 2008. New ${ }^{14} \mathrm{C}$ ages on cellulose from Diprotodon gut contents: explorations in oxidation chemistry and combustion. Radiocarbon 50:75-81.

Gretton, E. J. 2002. Palaeoceanographic changes offshore New Caledonia for the past 140,000 years. Unpublished Honours Thesis. Canberra: The Australian National University.

Hogg, A.G., L.K. Fifield, C.S.M. Turney, J.G. Palmer, R. Galbraith and M.G.K. Baillie 2006. Dating ancient wood by high sensitivity liquid scintillation counting and accelerator mass spectrometry - Pushing the boundaries. Quaternary Geochronology 1:241-248.

Hope, G.S. and J. Pask 1998. Tropical vegetational change in the late Pleistocene of New Caledonia. Palaeogeography, Palaeoclimatology, Palaeoecology 142:1-21.

Kershaw, A.P. 1986. Climatic change and Aboriginal burning in north-east Australia during the last two glacial/interglacial cycles. Nature 322:47-49.

Morat, Ph., J-M. Veillon and H.S. Mackee 1984. Floristic relationships of New Caledonian rainforest phanerogams. In F.J. Radovsky, P.H. Raven and S.H. Sohmer (eds) Biogeography of the Tropical Pacific: Proceedings of a Symposium, pp71-128. Honolulu: Bernice P. Bishop Museum.,

Morliere, A. and J.P. Rebert 1986. Rainfall shortage and El Niño-Southern Oscillation in New Caledonia, Southwestern Pacific. Monthly Weather Review 114:1131-1137.

Newnham, R.M., M.J. Vandergoes, M.H. Garnett, D.J. Lowe, C. Prior and P.C. Almond 2007. Test of AMS $14 \mathrm{C}$ dating of pollen concentrates using tephrochronology. Journal of Quaternary Science 22:37-51.

Read, J., T. Jaffré, E. Godrie, G.S. Hope and J-M. Veillon 2000. Structural and floristic characteristics of some monodominant and adjacent mixed rainforests in New Caledonia. Journal of Biogeography 27:233-250.

Stevenson, J. 2004. Late Holocene environmental change at Lac Saint Louis, New Caledonia. The Holocene 14(6):888-898.

Stevenson, J. 1998. Late Quaternary Environmental Change and the Impact of Melanesian Colonisation in New Caledonia. Unpublished PhD Thesis. Kensington: University of New South Wales.

Stevenson, J. and J.R. Dodson 1995. Palaeoenvironmental evidence for human settlement on New Caledonia. Archaeology in Oceania. 30:36-41. 
Stevenson, J., J.R. Dodson and I.P. Prosser 2001. A late Quaternary record of environmental change and human impact from New Caledonia. Palaeogeography, Palaeoclimatology, Palaeoecology 168:97-123.

Stevenson, J and G.S. Hope 2005. A comparison of late Quaternary forest changes in New Caledonia and northeastern Australia. Quaternary Research 64(3):372-383.

Turney, C.S.M., M.I. Bird, L.K. Fifield, A.P. Kershaw, R.G. Cresswell, G.M. Santos, M.L. di Tada, P.A. Hausladen and Z. Youping 2001a. Development of a robust C-14 chronology for Lynch's Crater (North Queensland, Australia) using different pretreatment strategies. Radiocarbon 43:45-54.

Turney, C.S.M., A.P. Kershaw, P. Moss, M.I. Bird, L.K. Fifield, R.G. Cresswell, G.M. Santos, M.L. di Tada, P. A. Hausladen and Y. Zhou 2001b. Redating the onset of burning at Lynch's Crater (North Queensland): implications for human settlement in Australia. Journal of Quaternary Science 16:767-771.

Vandergoes, M.J. and C.A. Prior 2003. AMS dating of pollen concentrates: a methodological study of Late Quaternary sediments from south Westland, New Zealand. Radiocarbon 45:479-491. 